PENCA, Jerneja, Biodiversity offsetting in transnational governance, Review of European, comparative \& international environmental law, 2014, Vol. 24, No. 1, pp. 93-102, doi: $\underline{10.1111 / \text { reel.12102 }}$ 


\title{
Biodiversity Offsetting in Transnational Governance
}

\author{
Jerneja Penca*
}

This article discusses the introduction of biodiversity offsets at the transnational governance level, at the vanguard of which is the practice by the Business and Biodiversity Offset Programme (BBOP). The institutional setting of the BBOP and the legal arrangement of biodiversity offsets at the international level are analyzed, zooming in on the institutional and normative interplay between the transnational governance network (BBOP) and the Convention on Biological Diversity as well as the Ramsar Convention. The significance of the case study lies in highlighting the cooperative but also exclusionary effect of transnational networks and in demonstrating how new governance structures implement treaty provisions, but rely on a contested interpretation, which then feeds back into the treaty process.

\section{INTRODUCTION}

Biodiversity offsets are drawing heightened levels of interest by policy makers in certain parts of the world as well as within international institutions as tools to generate biodiversity benefits. ${ }^{1}$ At the heart of the idea is that biodiversity damage caused in the course of an economic development project can be compensated. This strategy is simultaneously promising and controversial. On the one hand, the impact of offsets has been promoted as resulting in no loss of natural habitats by the creation of 'new, bigger or better nature sites' replacing those lost to development. ${ }^{2}$ On the other hand, critics view the concept as a false solution for wildlife and habitats, and argue that it will likely lead to increased damage. ${ }^{3}$

This article examines how this controversy is reflected in global biodiversity governance, looking in particular at how biodiversity offsetting as a legal and policy approach to biodiversity conservation has been explored in international avenues (intergovernmental treaty processes) and in parallel transnational structures (networks that include non-State entities). There has been an increasing scholarly interest in the impact of authority, law and regulation beyond the State in the area of environmental

\footnotetext{
* Corresponding author. Email: Jerneja.penca@gmail.com.

${ }^{1}$ For instance, biodiversity, more precisely habitat, offsetting looms large in European Union (EU) policy plans. While habitat offsetting is already required under three different EU Directives in case of damage to the Natura 2000 network of nature protection sites, the EU Biodiversity Strategy to halt biodiversity and ecosystem service loss by 2020 foresees its much more widespread use in land use decisions. The 'no net loss initiative', aiming at the implementation of biodiversity offsetting in some form, received a formal endorsement by the European Council in 2011, and a Working Group on No Net Loss of Ecosystems and their Services was established by the European Commission with a view to support the Commission in its preparation of a No Net Loss initiative. The Biodiversity Strategy is expected to be in place by 2015. See Communication from the European Commission, Our Life Insurance, Our Natural Capital: An EU Biodiversity Strategy to 2020, COM(2011) 244; and European Commission, 'No Net Loss', found at: <http://ec.europa.eu/environment/nature/biodiversity/nnl/index_en.htm>. Biodiversity offsets are also considered by the United Kingdom government; see Department for Environment, Food and Rural Affairs (Defra), 'Biodiversity Offsetting' (5 September 2013), found at: <https://www.gov.uk/biodiversity-offsetting>.

${ }^{2}$ See Defra, n. 1 above.

${ }^{3}$ See, e.g., <http://no-biodiversity-offsets.makenoise.org/>.
} 
protection, ${ }^{4}$ particularly in the context of climate change governance. Studies examine how transnational initiatives interact with the treaty process, ${ }^{5}$ but also provide insights into how to normatively think about this interplay. ${ }^{6}$ This body of literature has drawn attention not just to the fact that authority is increasingly spread across different actors and levels, but also to the significant interactions between intergovernmental and transnational environmental law. In doing so, these studies overcome the limited consideration of the role of treaties in (transnational) private governance, which could otherwise leave the impression that 'a choice is to be made between treaties and private law initiatives'. ${ }^{7}$ As part of the attempt to improve our understanding of the intersection between these two types of governance forms, this article examines the influence of substantive rules developed in international (intergovernmental) law on transnational governance processes, and vice versa. Notably, some of the norms that underpin the two forms of governance pull in different directions. Transnational law is motivated by speed and flexibility which contrasts with the notion of State consent that underlies intergovernmental law. Despite this, it is argued that the case of biodiversity offsetting demonstrates an overlapping, rather than antagonistic, relationship between the two approaches.

The transnational initiative under consideration in this article is the Business and Biodiversity Offsets Programme (BBOP), which seeks to implement biodiversity offsets on the transnational plane. The BBOP's operations and impacts will be discussed primarily in relation to the international regime established by the Convention on Biological Diversity (CBD) ${ }^{8}$ and to a lesser extent also the Ramsar Convention. ${ }^{9}$ The BBOP model serves as an example of how and why new collaborative networks consisting of States, businesses, nongovernmental organizations (NGOs), intergovernmental bodies and other actors attempt to implement treaties. Biodiversity offsets under the BBOP's framework represent a model of cooperation between the private and the public sector, State and non-State actors, the market and law. But the discussion in this article also highlights the conflicts that arise in, if not from, such close interactions on both the conceptual and operational level. The ultimate aim is not necessarily to discourage the advancement of either the mechanism or its particular institutional setting; rather, it is to continue building on the understanding of what non-traditional forms of governance can look like and how they work, including the anxieties that they may raise. The article can be considered an incursion into the questions and expectations that are raised more generally by transnational governance - and extend these also to the issue area of biodiversity, which has received less attention in this context than climate change.

\footnotetext{
${ }^{4}$ See, e.g., the editorials in 1:1 Transnational Environmental Law (2012), 1-29; see also L. Andonova, M. Betsill and H. Bulkeley, 'Transnational Climate Governance', 9:2 Global Environmental Politics (2009), 52, at 53-57.

${ }^{5}$ V. Heyvaert, 'What's in a Name? The Covenant of Mayors as Transnational Environmental Regulation', 22:1 Review of European, Comparative and International Environmental Law (2013), 78; S. Bernstein et al., 'A Tale of Two Copenhagens: Carbon Markets and Climate Governance', 39:1 Millennium: Journal of International Studies (2010), 161; G. Shaffer and M. Pollack, 'The Interaction between Formal and Informal International Lawmaking', in: J. Pauwelyn, R.A. Wessel and J. Wouters (eds.), Informal International Lawmaking (Oxford University Press, 2012), 241.

6 G. Shaffer and D. Bodansky, 'Transnationalism, Unilateralism and International Law', 1:1 Transnational Environmental Law (2012), 31.

${ }^{7}$ N. Affolder, 'The Market for Treaties, 11:1 Chicago Journal of International Law (2010), 159, at 161.

${ }^{8}$ Convention on Biological Diversity (Rio de Janeiro, 5 June 1992; in force 29 December 1993) ('CBD').

${ }^{9}$ Ramsar Convention on Wetlands of International Importance Especially as Waterfowl Habitat (Ramsar,

9 February 1971; in force 21 December 1975) ('Ramsar Convention').
} 
The article first traces how the idea of biodiversity offsets has been 'uploaded' from the national context to global biodiversity discourses. ${ }^{10}$ Next, it discusses the institutional and legal form of the mechanism at the transnational level. The article then examines how the norms generated by the transnational initiative interact with relevant international law, before drawing conclusions.

\section{BIODIVERSITY OFFSETS: FROM NATIONAL TO INTERNATIONAL TOOLS}

The idea of mitigating the damage to biodiversity in development projects beyond minimizing negative effects originates in the United States (US) national system of wetland mitigation banking. ${ }^{11}$ To ensure the integrity of waters, the 1972 US Federal Water Pollution Control Act (known also as the Clean Water Act) ${ }^{12}$ in Section 404 requires that anyone wishing to implement a project that would dredge or fill 'navigable waters' must apply for a permit from the US Army Corps of Engineers - the primary federal agency responsible for implementing the programme. The decision of the Corps may be such as to grant the permit and allow the project to proceed, reject it, or allow it to proceed on the condition that the loss of the site is compensated for.

By the 1980s, the practice to require compensatory mitigation developed into a standard feature of development activities involving practically all waters of the US, and particularly wetlands. The measure led to some controversy with respect to the wide administrative discretion permitted under the law, and ultimately the intrusion into property rights, ${ }^{13}$ and the adequacy of the ecological benefits of the programme. ${ }^{14} \mathrm{At}$ first, developers of mitigation sites were only public entities, but the early 1990s saw the development of the first commercial projects, which grew rapidly in the next decade. ${ }^{15}$ Under this commercial model, third-party entrepreneurs develop mitigation projects and sell 'credits' for these sites, which can be freely purchased by the permittee as an alternative to creating a wetland himself. ${ }^{16}$ This evolution marked an important shift in wetland regulation: on-site offsetting gave way to off-site mitigation, and led to

\footnotetext{
${ }^{10}$ H.H. Koh, 'Why Transnational Law Matters', 24:4 Penn State International Law Review (2005), 745, at 753 .

${ }^{11}$ V. Heyvaert and T. Etty, 'Introducing Transnational Environmental Law', 1:1 Transnational Environmental Law (2012), 1; M.J. Bean and L.E. Dwyer, 'Mitigation Banking and an Endangered Species Conservation Tool', 30:7 Environmental Law Review (2000), 10537; P. Hough and M. Robertson, 'Mitigation under Section 404 of the Clean Water Act: Where It Comes from, What It Means', 17:1 Wetlands Ecology and Management (2009), 15; M.C. Blumm and D.B. Zaleha, 'Federal Wetlands Protection under the Clean Water Act: Regulatory Ambivalence, Intergovernmental Tension, and a Call for Reform', 60:4 University of Colorado Law Review (1989), 695.

${ }^{12}$ Clean Water Act, 33 USC $\$ \S 1251-1387$.

${ }^{13}$ See M.C. Blumm and D.B. Zaleha, n. 11 above, at 698; J.G. Laitos, 'Water Rights, Clean Water Act Section 404 Permitting and the Takings Clause', 60:4 University of Colorado Law Review (1989), 901.

${ }^{14}$ See, e.g., W.L. Andreen, 'Water Quality Today - Has the Clean Water Act Been a Success?', 55:3 Alabama Law Review (2003), 537; M.M. Robertson, 'The Neoliberalization of Ecosystem Services: Wetland Mitigation Banking and Problems in Environmental Governance, 35:3 Geoforum (2004), 361. ${ }^{15}$ By 2005 there were at least 450 mitigation banks (sites) and 198 sites pending approval. United States Environmental Protection Agency, 'Mitigation Banking Fact Sheet', found at: <http://www.epa.gov/owow/wetlands/facts/fact16.html>.

${ }^{16}$ Ibid.
} 
the establishment of 'wetland banks' ${ }^{17}$ Significantly, while on-site mitigation was seen as a form of prescriptive regulation, banking is deemed a market mechanism. ${ }^{18}$ In the case of US wetlands banking, the concept of 'offsets' was built on the overarching goal of 'no net loss' of biodiversity. ${ }^{19}$

The introduction of the model of biodiversity offsetting to international conservation avenues is usually associated with the act by a private actor within an international institution. At the World Conservation Congress of the International Union for Conservation of Nature (IUCN) in 2004, the mining company Rio Tinto announced the public commitment that it would aim to achieve a 'net positive impact' in sites where it operates. ${ }^{20}$ Rio Tinto's move was part of its ongoing corporate accountability efforts to finding solutions for the damage that its activities have been causing to rare and threatened habitats. A move 'beyond compliance' also acted as recognition of the fact that legislation often fails to fulfil legitimacy criteria:

while operating within the law, the mining industry was collectively failing to meet some expectations of society. Legislation is a lagging indicator of society's expectations, so even full legal compliance falls short of what some key sectors of society expect responsible businesses to achieve. ${ }^{21}$

Starting with its internal review of significant strategic issues in 1996, the company set out a comprehensive biodiversity policy with the pledge of having a "net positive impact' on biodiversity, indicating that communities or regions will ultimately benefit from their presence. ${ }^{22}$ In 2010, the company signed an agreement with the IUCN with the objective to improve Rio Tinto's environmental management and delivery of conservation outcomes, to strengthen IUCN and Rio Tinto capacities for market-based approaches to conservation, and to contribute to industry-wide improvements in the mining and associated sectors. ${ }^{23}$ Notably, at the transnational level, the adopted principle of 'no net loss' was launched as a 'net gain' target. While the content of the principle will be analyzed below, it is significant to note here that the principle of 'net gain' is in fact a stricter version of the 'no net loss' principle found in the US model, as it requires a residual benefit in addition to the strict compensation. This demonstrates how national law can be altered during its translation to transnational practice.

Simultaneously with Rio Tinto's endeavour to establish itself as an environmental leader in the mining sector, biodiversity offsets began to be explored in a more structured manner for wider applicability. In 2004, a study conducted by the asset management company Insight Investment and the IUCN concluded that the mechanism is widely seen as a useful tool for managing the adverse impacts of development

\footnotetext{
${ }^{17}$ J. Salzman and J.B. Ruhl, “No Net Loss": Instrument Choice in Wetlands Protection', in: J. Freeman and C.D. Kolstad (eds.), Moving to Markets in Environmental Regulation: Lessons from Twenty Years of Experience (Oxford University Press, 2006), 324.

18 Ibid.

${ }^{19}$ Ibid.

20 IUCN, 'IUCN $\quad-\quad$ Rio Tinto Relationship', found at: <http://www.iucn.org/about/work/programmes/business/bbp_work/by_engagement/rio_tinto/>

${ }^{21}$ Rio Tinto, Rio Tinto's Biodiversity Strategy Sustaining a Natural Balance (2004), found at: $<$ http://www.riotinto.com/SustainableReview/Landaccess/programmes/Biodiversity/pdf/BiodiversitySt rategy.pdf $>$, at 2

22 Ibid.

${ }^{23}$ See IUCN, n. 20 above.
} 
activities on biodiversity. ${ }^{24}$ Despite this, the study recognized that some conservation groups deemed an outright ban on habitat conversion a preferred strategy. It discussed the controversies enshrined in the idea of implementing offsetting conservation activities far from the original development site, as well as in potential trading of conservation and socio-economic benefits, rather than delivering both. Notwithstanding these concerns and certain risks involved in the implementation of projects, the authors continued to elaborate on the concept with a particular focus on developing credible and transparent standards, methodologies and guidelines for biodiversity offsets, and on developing pilot projects.

The impending launch of biodiversity offsetting as regulation calls for reflection on its coming into being. Whilst concerns related to participation are usually raised in assessing the legitimacy of governance arrangements, ${ }^{25}$ they are often overlooked in the early development of a new regulatory tool. This is so even when the regulatory tool's very existence is debated. Once a specific strategy is accepted as a legitimate method for tackling an environmental problem, the possibility of a critique is limited to details, excluding its underlying principles. The issue and role of participation in the crafting phase of the initiative is thus examined more closely in the next section, which looks at the development and composition of the institutional setting of biodiversity offsets at the transnational level, focusing on the Business and Biodiversity Offset Programme.

\section{INSTITUTIONALIZATION OF OFFSETS AT THE TRANSNATIONAL LEVEL}

Following the release of the IUCN report, efforts were made to institutionalize the support for the mechanism. In the same year (2004), an NGO called Forest Trends launched the BBOP, which has since become the key international focal point for biodiversity offsets as a regulatory strategy. ${ }^{26}$ The BBOP is a consortium of NGOs, companies, governments and financial institutions. It is an offshoot of the NGO, but it has its own secretariat, which is aided by a larger NGO, the Wildlife Conservation Society. ${ }^{27}$ The BBOP is funded by a variety of sources, including governmental agencies of some Western countries, oil and mining companies, large NGOs, foundations and intergovernmental agencies. ${ }^{28}$

\footnotetext{
${ }^{24}$ K. ten Kate, J. Bishop and R. Bayon, Biodiversity Offsets: Views, Experience, and the Business Case (IUCN, 2004).

${ }^{25}$ D. Bodansky, 'The Legitimacy of International Governance: A Coming Challenge for International Environmental Law', 93:3 American Journal of International Law (1999), 596.

${ }^{26}$ There have also been regional initiatives for biodiversity banking schemes. One such initiative is undertaken by the European Commission, which has looked into the scope for using Habitat Banking to protect biodiversity at the EU level; see K. ten Kate, J. Treweek and J. Ekstrom, The Use of Marketbased Instruments for Biodiversity Protection - The Case of Habitat Banking (Eftec, 2010), found at: <http://ec.europa.eu/environment/enveco/pdf/eftec_habitat_technical_report.pdf>. Another study was undertaken by the United Nations Development Programme (UNDP) and the financial services company PricewaterhouseCoopers, examining the feasibility of habitat banking in the Latin America and the Caribbean region; A. Bovarnick, C. Knight and J. Stephenson, Habitat Banking in Latin America and Caribbean: A Feasibility Assessment (UNDP, 2010).

27 The Wildlife Conservation Society was funded in 1895, and manages five parks in New York City as well as about 500 projects in 60 countries; see Wildlife Conservation Society, 'About Us', found at: $<$ http://www.wcs.org/about-us.aspx>.

${ }^{28}$ See Business and Biodiversity Offset Programme (BBOP), Business, Biodiversity Offsets and BBOP: An Overview (BBOP, 2009), found at: <http://www.forest-trends.org/documents/files/doc_3125.pdf>
} 
An Executive Committee guides the BBOP in its operations and its official documents additionally undergo an endorsement of an advisory group. The BBOP builds on inclusiveness; apart from a large number of members in its advisory group, efforts have been made to ensure that different groups of stakeholders are represented in both bodies. The membership lists allow for some interesting observations about their composition and linkages to various bodies. The advisory group's corporate members almost exclusively consist of extractive industries and environmental consultancies. Also present are financial institutions, environment departments or ministries and large NGOs. Finally, among the members are international environmental institutions, such as IUCN, the United Nations Environment Programme (UNEP) World Conservation Monitoring Centre and the Ramsar Convention, but notably, not the Secretariat of the CBD (although parties to the CBD have endorsed the programme in its decisions; see below). One of the seven members of the current Executive Committee is also a member of the steering committee of another emerging market mechanism, the Green Development Initiative. ${ }^{29}$

The BBOP is formally (and may be considered by some) an NGO, but the sheer variety of actors involved in its governance suggests that it should rather be regarded as a transnational network than a fixed-membership group. In relation to the study of pluricentric governance, particularly in the environmental arena, the literature on transnational networks has highlighted the importance of non-hierarchical structures that include actors other than States, ${ }^{30}$ and the horizontal flow of communication. ${ }^{31}$ It has done so through showing how the authority is constituted not only by power and politics, but also by shared knowledge and values. ${ }^{32}$ The lessons from this body of scholarship are significant in the BBOP's context. First, they provide an accurate description of the BBOP's modus operandi. They rationalize the impression that individual decisions are a result of pragmatic considerations, rather than of a strategy with preconceived answers. Second, these studies invite us to investigate the substance of the values and objectives that drive the transnational network, and its composition. As a final step, they draw attention to the wide outreach of certain actors, at the cost of others. While emphasizing horizontality within the network, detailed study of particular transnational networks helps highlight those actors and views that are excluded, thus helping reveal the bias in environmental governance.

('BBOP, 2009') (for funding sources up to 2009); and BBOP, To No Net Loss and Beyond: An Overview of the Business and Biodiversity Offsets Programme (BBOP, 2013), found at: <http://www.foresttrends.org/documents/files/doc_3319.pdf> ('BBOP, 2013') (for funding sources between 2009 and 2012).

${ }^{29}$ This is the representative of the government of the Netherlands in BBOP.

30 T. Risse-Kappen (ed.) Bringing Transnational Relations Back In: Non-State Actors, Domestic Structures and International Institutions (Cambridge University Press, 1995); R. Lipschutz, Global Civil Society and Global Environmental Governance: The Politics of Nature from Place to Planet (SUNY Press, 1996); P. Wapner, Environmental Activism and World Civic Politics (SUNY Press, 1996); M. Keck and K. Sikkink, Activists Beyond Borders: Advocacy Networks in International Politics (Cornell University Press, 1998); T. Risse, S.C. Ropp, and K. Sikkink (eds.), The Power of Human Rights: International Norms and Domestic Change (Cambridge University Press, 1999); P. Newell, Climate for Change: Non-State Actors and the Global Politics of the Greenhouse (Cambridge University Press, 2000).

${ }^{31}$ M.E. Keck and K. Sikkink, 'Transnational Advocacy Networks in International and Regional Politics', 51:159 International Social Science Journal (1999), 89, at 91.

${ }^{32}$ P. Haas, Saving the Mediterranean: The Politics of International Environmental Cooperation (Columbia University Press, 1990); R. Lipschutz, n. 30 above; M. Keck and K. Sikkink, n. 30 above. 
As the institutionalization of the mechanism takes place at the transnational level, many remain sceptical about the idea of biodiversity offsets. The BBOP is keen on generating an impression that offsets are a consensual regulatory strategy, agreed upon by different 'groups in society with diverse perspectives on environment and development from many different countries' ${ }^{33}$ This claim is in stark contrast with the opposition to offsets by local campaigners, some smaller NGOs and individuals. They maintain that the idea of biodiversity offsets 'completely and utterly ignores the complexity and diversity of local society as much as it ignores the complexity and diversity of the nature in our landscapes. Questions are also posed over how offsetting can be achieved where knowledge and awareness of what is being offset are lacking. ${ }^{34}$

These critical opposing views have, however, not been properly discussed in policy considerations, including in the context of decisions by the CBD Conference of the Parties (COP), which endorsed the BBOP and the offsetting mechanism as such (see below). In addition, such views are absent from the wealth of material promoting the advantages of offsets. The alienation of such views to separate, even 'outside', channels of communication, ${ }^{35}$ and to occasional statements to the media, ${ }^{36}$ means that they fail to exert the same level of influence as the voices of those promoting the initiative. Most fundamentally, the decision of whether or not to embrace biodiversity offsets as a sound conservation strategy is decided in the absence of such voices, which have missed the opportunity to influence the very terms and nature of the debate. The differentiation in participative roles embeds the bias in the procedure.

In addition to their exclusion from shaping policy, these dissenting groups find the usual strategies for objection to the ongoing processes particularly difficult, given that international institutions and governments back the idea of biodiversity offsetting. Social action as one of the common strategies for challenging governments' plans is problematic because (local) governments have the power to proclaim protests as illegitimate. ${ }^{37}$ Even more recognized political tools, such as referendums, may prove insufficient: in Poland, the valid result of a referendum ruling against a development project was entirely disregarded by the authorities. ${ }^{38}$

A study of the more grassroots voices excluded from the transnational network of institutions, private and non-governmental organizations, remind us of the extent to which the current institutional structures are constituted in favour of those with more political or economic power. This, in turn, means that dominant policy and legal strategies do not necessarily reflect a wide consensus and reconfirms the participatory imbalance between NGOs in international institutions and the global civil society

\footnotetext{
${ }^{33}$ See BBOP, 2009, n. 28 above, at 7.

${ }^{34}$ Europeantrees, 'Biodiversity Offsetting Will Destroy Much More than Nature (30 October 2013), found at: <http://europeantrees.wordpress.com/2013/10/30/biodiversity-offsetting-will-destroy-muchmore-than-nature/ $>$.

${ }^{35}$ See $n .3$ above.

${ }^{36}$ E.g. H. Mowat and H. Anderson, 'Biodiversity Offsetting Smacks of Middle Class Environmentalism', The Guardian Environment Blog (15 January 2014).

37 See, e.g., Cipra, 'Wall Blocks Centres of Six Cities' (8 November 2010), found at: $<$ http://www.cipra.org/en/media-releases/the-wall >

${ }^{38}$ European Parliament, Working Document on the fact-finding mission to Lower Silesia, Poland, from 29 to 31 May 2013 (22 October 2013).
} 
voice. ${ }^{39}$ The exclusion of a wider and more representative civil society's voice in addition to the large, Northern NGOs, substantially reduces public participation in environmental policy. The engagement of the public in decision making, including their right to reject the model altogether, would be expected, as the decisions involved in biodiversity offsetting affect the immediate environment in which people live - either through hosting development projects or their offsets. ${ }^{40}$

\section{THE LEGAL FORM OF TRANSNATIONAL BIODIVERSITY OFFSETTING}

Under the BBOP's framework, biodiversity offsets function as a voluntary mechanism. The deals leading to biodiversity offsets are normally contractual arrangements between the developer and the entity implementing the project - an NGO or another business. Businesses may use the BBOP's services and framework to implement an offset project for several reasons, including a legal obligation. In a growing number of countries offsets are required by law - at either a national or regional level. ${ }^{41}$ This is exemplified by the procedural requirement under an environmental impact assessment where residual impacts on biodiversity are expected to exceed a certain threshold. Where the impact of such a development will still be acceptable (rather than so significant as to trigger a rejection of a project), offsets should take place after the appropriate mitigation measures are taken..$^{42}$ The developer is required to design an offset process in detail, including making decisions on the size and type of compensation. ${ }^{43}$

Apart from legal requirements, another reason for using offsets is pressure from capital lenders. As of 2012, offsets have become a requirement for bank loans of both the International Finance Corporation of the World Bank and a large number of signatories

\footnotetext{
${ }^{39}$ See, e.g., B.S. Chimni, 'International Institutions Today: An Imperial Global State in the Making', 15:1 European Journal of International Law (2009), 1, at 26-27.

${ }^{40}$ See Europeantrees, n. 34 above.

${ }^{41}$ Relevant laws for biodiversity offsetting are in place in Australia, Brazil, Canada, Chile, China, Colombia, European Union, Germany, Mexico, Netherlands, Pakistan, Paraguay, South Africa, Switzerland and the United States; and are being planned in a number of other countries. See N. Doswald et al., Biodiversity Offsets: Voluntary and Compliance Regimes. A Review of Existing Schemes, Initiatives and Guidance for Financial Institutions (UNEP-World Conservation Monitoring Centre and UNEP Finance Initiative, 2009), found at: <http://www.unepfi.org/fileadmin/documents/Biodiversity_Offsets-

Voluntary_and_Compliance_Regimes.pdf>, at 9; B. Madsen et al., State of Biodiversity Markets Report: Offset and Compensation Programs Worldwide (Forest Trends, 2011); see also n. 1 above.

${ }^{42}$ See, e.g., Republic of South Africa, Provincial Government of the Western Cape, Department of Environmental Affairs \& Development Planning, 'Provincial Guideline on Biodiversity Offsets' (2007), found at: 〈http://www.westerncape.gov.za/text/2007/3/pgwcoffsetsguidelinedraft_5march_07.pdf〉

${ }^{43}$ Vedanta, 'Gamsberg Zinc Project, Offset Report' (2013).
} 
to the Equator Principles. ${ }^{44}$ Most regional development banks have a similar requirement. ${ }^{45}$

The prerequisite to offset has also been established by some industries, either in their own internal social and environmental policies ${ }^{46}$ or as part of initiatives articulating sector-specific standards. ${ }^{47}$ Finally, offsets may be undertaken as a voluntary measure by businesses to improve the relationship with stakeholders. By going 'the extra mile', businesses are more likely to gain a social license to operate (i.e. gain acceptance and approval by the local community and stakeholders), get improved access to capital and earn the confidence of government regulators, which could increase permissions. ${ }^{48}$ The above reasoning can enable businesses to offset in one country as a consequence of a legal requirement or social expectation in another country.

\section{INTERPLAY BETWEEN TRANSNATIONAL AND INTERNATIONAL LAW}

To realize the potential of biodiversity offsets as a regulatory option beyond the national level, the BBOP's ambition is to provide comprehensive guidance for implementing biodiversity offsets, by sharing 'best practices'. Its primary output is a framework of principles and methodologies to guide biodiversity offsetting, ${ }^{49}$ as well as promoting the use of such a mechanism.

The tools developed by the BBOP represent a practical approach for developers interested in implementing offsetting programmes. These tools can be seen as a

\footnotetext{
${ }^{44}$ The Equator Principles refer to a set of commitments to environmental and social standards and procedures in project financing. At present, 76 financial institutions are recorded to have officially adopted the principles, which covers over 70 percent of international project finance debt in emerging markets. Equator Principles, 'About the Equator Principles', found at: <http://www.equatorprinciples.com/index.php/about-ep>. International Finance Corporation (IFC) performance standards (and the relevant World Bank Group Environmental, Health and Safety Guidelines) provide a source of applicable environmental and social standards. The relevant IFC Performance Standard 6 ('Biodiversity Conservation and Sustainable Management of Living Natural Resources') requires adherence to the principle of 'mitigation hierarchy' and suggests implementing biodiversity offsets after other measures have been exhausted; IFC, 'IFC Performance Standard 6' (1 January 2012), found at: <http://www.ifc.org/wps/wcm/connect/bff0a28049a790d6b835faa8c6a8312a/PS6_English_2012.pdf? MOD=AJPERES $>$; see also Performance Standard 3 ('Resource Efficiency and Pollution Prevention') which also suggests offset as a strategy to reduce negative impacts on a degraded land; IFC, 'IFC Performance Standard 3' (1 January 2012), found at: <http://www.ifc.org/wps/wcm/connect/25356f8049a78eeeb804faa8c6a8312a/PS3_English_2012.pdf? MOD=AJPERES $>$.

${ }^{45}$ See N. Doswald et al., n. 41 above, at 15.

${ }^{46}$ Among the BBOP's case studies there is for instance a mining corporation, Newmont, which has been working on their corporate strategies on biodiversity, and explored biodiversity offsets as tools for conservation within that context; see BBOP, BBOP Pilot Project Case Study: Akyem Gold Mining Project (2009), found at: 〈http://www.forest-trends.org/documents/files/doc_3122.pdf〉.

${ }^{47}$ For instance, a partnership between four large oil and gas companies and four conservation organizations, which existed between 2001 and 2007, produced guidance for integrating biodiversity conservation into upstream oil and gas development. The guidance proposes to offset residual impacts by creating or managing habitat for impacted areas. See The Energy \& Biodiversity Initiative, 'Good Practice in the Prevention and Mitigation of Primary and Secondary Biodiversity Impacts' (undated), found at: 〈http://www.theebi.org/pdfs/practice.pdf>.

${ }^{48} \mathrm{CBD}$, Biodiversity Offsets and the Business and Biodiversity Offsets Programme (BBOP) (UN Doc. UNEP/CBD/COP/9/Inf/29, 18 March 2008), at 10; N. Gunningham, R. A. Kagan, and D. Thornton, Shades of green: business, regulation, and environment (Stanford University Press, 2003)

${ }^{49}$ BBOP, 'Standard \& Guidelines', found at: <http://bbop.forest-trends.org/pages/guidelines>.
} 
reflection of the approaches adopted by the nongovernmental sector and discussed in the framework of transnational governance, with no linkages to the intergovernmental treaty process. But, as this section will demonstrate, some unequivocal ties can be established between the BBOP's operation and international law. First, the BBOP's claims to be implementing the CBD's treaty provisions demonstrate how international law 'trickles down' into concrete mechanisms. Second, some of the BBOP's principles have found their way back into the CBD treaty process, showing how the treaty process draws on non-State practice. This is consonant with the BBOP's public ambition of tying its output to the global biodiversity governance architecture, as stated by its goal of 'support[ing] the development of institutional, legal and regulatory frameworks to require and implement biodiversity offsets' ${ }^{50}$ The flow of this interaction is sketched in Figure 1.

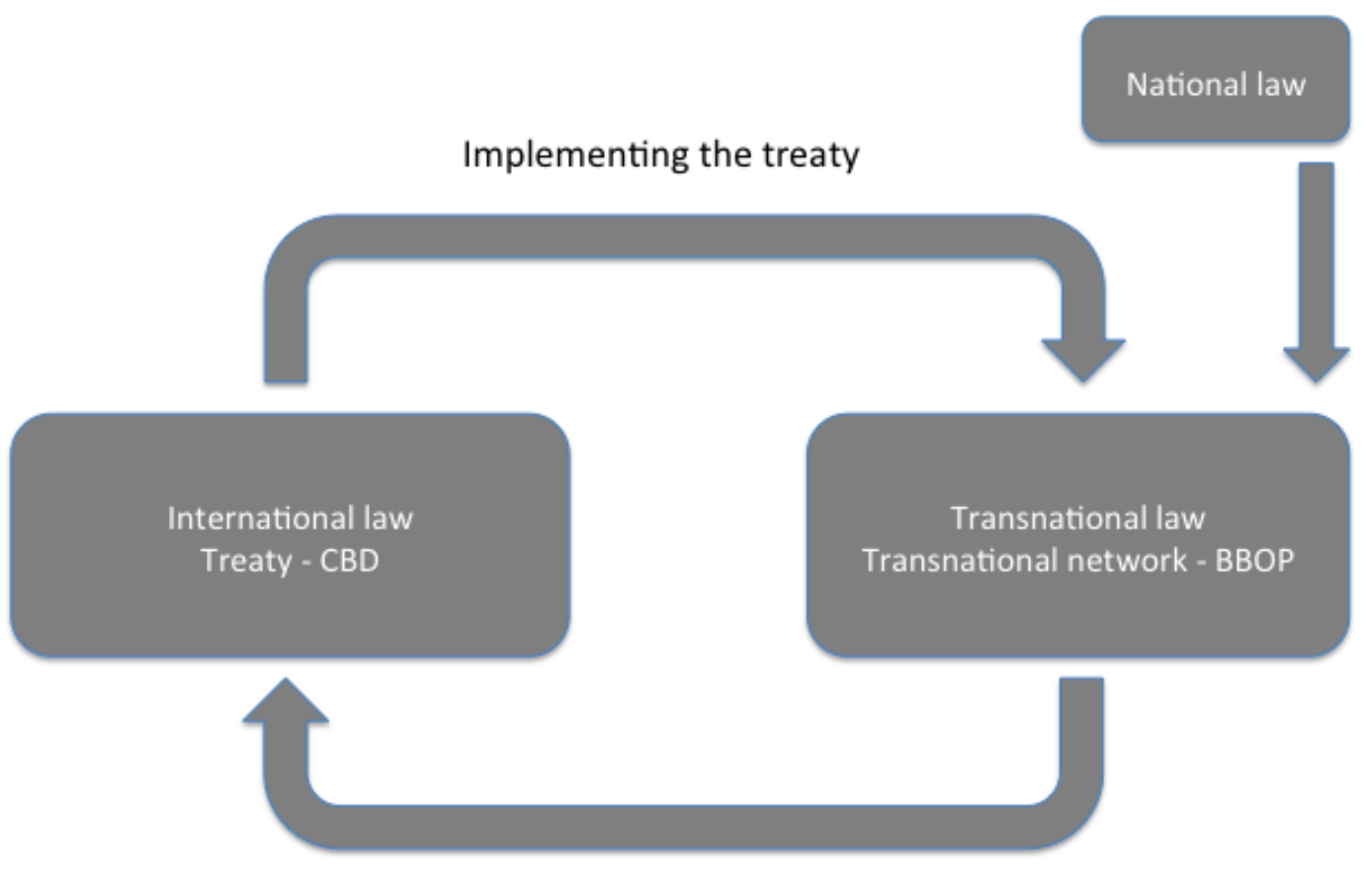

Legitimizing the initiative

\section{FIGURE 1. The interaction between governance forms.}

Apart from documenting the dialogue between different forms of governance, the following sub-sections will examine the question of compatibility of norms in this twoway process, particularly with the view of safeguarding the integrity of existing international norms and ensuring that the accomplished levels of environmental protection are not lowered. With regard to downloading (implementing) international law, the BBOP's practice needs to accurately reflect the actual CBD's provisions. With respect to uploading (feeding) transnational law back into the treaty process, it seems sensible to carefully scrutinize the substance of the norms that are imported into the realm of international law.

\footnotetext{
${ }^{50}$ See BBOP, 2009, n. 28 above, at 4.
} 


\section{TRANSNATIONAL LAW IMPLEMENTING A TREATY}

At the launch of the initiative, the BBOP stated that it is responding to the intergovernmental target 'to achieve by 2010 a significant reduction of the current rate of biodiversity loss at the global, regional and national level as a contribution to poverty alleviation and to the benefit of all life on Earth'. ${ }^{51}$ It presented itself as a 'new and innovative mechanism' and a 'practical approach' to help meet this goal. ${ }^{52}$ Biodiversity offsets thus emerged as a concrete tool to operationalize the legal goal of 'biodiversity conservation' and the ambitious but largely imprecise provisions of the CBD. ${ }^{53}$ The mechanism proposes alternative steps that can be taken to implement treaty provisions and suggests that it is capable of putting the treaty into practice in a way that States so far have not managed to. It promises to overcome the sluggishness of the national actions primarily targeted by the treaty processes, which resulted in continuous biodiversity loss, including missing the 2010 target. ${ }^{54}$ The BBOP thus remains loyal to the treaty's original and strategic objectives, but presents itself as a new way of achieving those objectives.

\section{THE TREATY AS A LEGITIMIZING SOURCE FOR TRANSNATIONAL INITIATIVES}

The BBOP has been seeking integration of its transitional initiative into the treaty process. After developing the framework, together with the objectives and the principles, the BBOP - at the request of the Netherlands, that is, via a governmental intermediary - submitted the idea of biodiversity offsets to the ninth COP of the CBD in 2008. Its work was explicitly endorsed in COP decisions in the same year. Two of these regard biodiversity offsets as a case of new and innovative financial mechanism deserving of attention and exploration with a view to generating funding. ${ }^{55}$ However, whilst promoted as one of the promising financing options, biodiversity offset mechanisms were to only be 'consider[ed] where relevant and appropriate while ensuring that they are not used to undermine unique components of biodiversity' ${ }^{56}$ The BBOP was identified in a further decision, concerned with promoting business engagement, in the context of disseminating tools and best practices as a priority action to better engage business in biodiversity conservation. ${ }^{57}$ This decision singles out the BBOP as an example of a 'relevant organization or initiative'. It highlights its

\footnotetext{
${ }^{51} \mathrm{CBD}$, Biodiversity Offsets and the Business and Biodiversity Offsets Programme (BBOP) (UN Doc. UNEP/CBD/COP/9/Inf/29, 18 March 2008) ('CBD, BBOP'), at 2 and 50, implicitly referring to CBD, Decision VI/26, Strategic Plan for the Convention on Biological Diversity (UN Doc. UNEP/CBD/COP/6/20, 19 April 2002). The target was further endorsed by the World Summit on Sustainable Development and the United Nations General Assembly and incorporated into the Millennium Development Goals; see CBD, '2010 Biodiversity Target', found at: $<$ http://www.cbd.int/2010-target/>.

${ }^{52}$ See CBD, BBOP, n. 51 above, at 2.

${ }^{53}$ S.R. Harrop and D.J. Pritchard, 'A Hard Instrument Goes Soft: The Implications of the Convention on Biological Diversity’s Current Trajectory’, 21:2 Global Environmental Change (2011), 474.

${ }^{54}$ See, e.g., S.H.M. Butchart et al., 'Global Biodiversity: Indicators of Recent Declines', $328: 5982$ Science (2010), 1164.

55 CBD, Decision IX/11, Review of Implementation of Articles 20 and 21 (UN Doc. UNEP/CBD/COP/9/29, 9 October 2008); CBD, Decision IX/18, Protected Areas (UN Doc. UNEP/CBD/COP/9/29, 9 October 2008).

${ }^{56} \mathrm{CBD}$, Decision IX/11, n. 55 above, at paragraph 10, Goal 4.2.

${ }^{57}$ CBD, Decision IX/26, Promoting Business Engagement (UN Doc. UNEP/CBD/COP/9/29, 9 October 2008).
} 
collaborative role with the $\mathrm{CBD}$, contributing case studies, methodologies, tools and guidelines on biodiversity offsets. ${ }^{58}$ It also makes explicit mention of the BBOP's role in creating 'relevant national and regional policy frameworks' ${ }^{59}$

In the same year, the Ramsar Convention's COP also considered both biodiversity offsetting and the BBOP's work. In a resolution on the treaty's relations with the business sector, it mentions offsets as a 'last option' policy of ecosystem management, and the BBOP as a potential contributor of guidelines and standards in that context. ${ }^{60}$ Taken together, these endorsements of the BBOP's work imply an acceptance that the norms it produces are authoritative in guiding the practice of biodiversity offsetting. The wording of the decisions explicitly foresees the influence by the BBOP in creating broadly acceptable standards for this mechanism.

In contextualizing the acknowledgment of the BBOP within the treaties, it is important to note, first, that these two conventions, particularly the CBD, are widely inclusive. ${ }^{61}$ This lends the BBOP support from a large number of State actors. Second, States parties to the CBD have not been equally supportive towards all transnational initiatives or 'innovative' regulatory tools. For instance, they have so far explicitly refused to mention the Green Development Initiative in a COP decision. ${ }^{62}$ The BBOP and its norms seem to be enjoying a reasonably high level of credibility and the CBD's endorsement of the BBOP can be seen as a significant recognition.

The BBOP's mentioning in decisions by two treaty bodies offers a boost to the legitimacy of the initiative and may result in its rules becoming more widely adopted. This would be the case if biodiversity offsets become a mandatory requirement in more national, international and transnational processes. Clearly, the BBOP is interested in operating outside of international legal structures while simultaneously seeking recognition within such structures. While transnational law allows for flexibility, faster action and informality at the output, process and actor level, ${ }^{63}$ the acceptance by treaty bodies considerably increases the perception of the mechanism's relevance and appropriateness. The mention by the treaty bodies may create better chances for the worldwide expansion of biodiversity offsets and the evolution of the BBOP's practices into standard practice for large development projects, thereby helping to meet the BBOP's ambitions. ${ }^{64}$

\section{COMPLEMENTARITY BETWEEN TRANSNATIONAL AND INTERNATIONAL} NORMS

\footnotetext{
${ }^{58}$ Ibid., Annex (Framework of Priority Actions on Business, 2008-2010), at paragraph 5.

${ }^{59}$ Ibid.

${ }^{60}$ Ramsar Convention, Resolution X.12, Principles for Partnerships between the Ramsar Convention and the Business Sector, found at: 〈http://www.ramsar.org/pdf/res/key_res_x_12_e.pdf>, at paragraph 15 .

${ }^{61}$ To date, there are 194 parties to the CBD and 168 parties to the Ramsar Convention.

${ }^{62}$ S. Jungcurt et al., 'CBD COP 10 Highlights, 19 October 2010', 9:534 Earth Negotiations Bulletin (2010).

63 J. Pauwelyn, R. Wessel and J. Wouters, 'An Introduction to Informal International Lawmaking', in: J. Pauwelyn et al., n. 5 above, 1, at 14, describe informal international law as 'dispens[ing] with certain formalities traditionally linked to international law'.

${ }^{64}$ See BBOP, 2009, n. 28 above, at 3.
} 
The transnational law's efforts of cooperation with the treaty can be seen as part of the increasing resort to law and law-like arrangements in ordering international affairs. ${ }^{65}$ However, in doing so, the treaty provisions and COP decisions have not retained the exclusive rule-making authority. The case of the BBOP shows that the CBD parties, States, acknowledge the attempts at asserting authority by a transnational network and have sought to incorporate these efforts into the CBD's body of norms as 'best practice', specifically allowing for the possibility that these norms developed outside the treaty act as guidance to the implementation of treaty provisions. While many operational details of biodiversity offsets as set forth by the BBOP are likely to change over time, depending mostly on the emerging practice, the broader principles guiding the mechanism certainly have a more permanent status. Of such nature are the key principles of 'no net loss' and 'mitigation hierarchy'. From the point of view of the treaty's normative guidance being influenced by action of a transnational network outside the treaty, it is important to examine the substance and effect of these 'imported' principles.

At the core of the biodiversity offsetting mechanism stand two fresh principles: 'no net loss' and 'mitigation hierarchy'. ${ }^{66}$ The former demands that biodiversity offsets are designed and implemented so as to achieve, after restoration, no loss and 'ideally, a net gain' of biodiversity. ${ }^{67}$ The latter dictates that prevention and mitigation measures (avoidance, minimization and rehabilitation, respectively) need to be exhausted before offset projects are started. In conjunction, these principles ensure the integrity of the mechanism and aim to rebut one of the major concerns about biodiversity offsets, that is, that large projects with unacceptable impacts on biodiversity will be allowed to proceed.

These two principles are new to the body of international biodiversity law. Existing norms relate to an obligation to avoid and minimize damage. ${ }^{68}$ They foresee planning

\footnotetext{
65 See, J. Goldstein, et al.. 'Introduction: Legalization and World Politics', 54:3 International Organization (2000), 385; R. Hirschl, The Judicialization of Politics, in: K.E. Whittington, R.D. Kelemen and G.A. Caldeira (eds.), The Oxford Handbook of Law and Politics (Oxford University Press, 2008), 119.

${ }^{66}$ BBOP, 'Mitigation Hierarchy', found at: <http://bbop.forest-trends.org/pages/mitigation_hierarchy>. ${ }^{67}$ Ibid.

${ }^{68}$ CBD, n. 8 above, Article 14(a), 14(b) and 14(d); the Ramsar Convention, n. 9 above, does not contain similarly explicit provisions on avoidance and minimization, but a number of COP decisions have endorsed this principle, in line with the fact that the Ramsar Convention has largely evolved through subsequent COP resolutions (on this, see M.J. Bowman, 'The Ramsar Convention Comes of Age', 42:1 Netherlands International Law Review (1995), 1); see, e.g., Ramsar Convention, Resolution VII.12, Sites in the Ramsar List of Wetlands of International Importance: Official Descriptions, Conservation Status, and Management Plans, Including the Situation of Particular Sites in the Territories of Specific Contracting Parties, found at: <http://archive.ramsar.org/pdf/res/key_res_vii.12e.pdf>, Annex II, Practical Principle 5; Resolution VIII.9, 'Guidelines for Incorporating Biodiversity-related Issues into Environmental Impact Assessment Legislation and/or Processes and in Strategic Environmental Assessment' Adopted by the Convention on Biological Diversity (CBD), and Their Relevance to the Ramsar Convention, found at: <http://www.ramsar.org/sites/default/files/documents/pdf/res/key_res_viii_09_e.pdf>, Annex, paragraphs 1(iv), 20(i), 25 and 39; Resolution X.17, Environmental Impact Assessment and Strategic Environmental Assessment: Updated Scientific and Technical Guidance, found at: <http://archive.ramsar.org/pdf/res/key_res_x_17_e.pdf>, Annex, at paragraphs 23, 24(a), 25(j), 32; Resolution X.26, Wetlands and Extractive Industries, found at: <http://archive.ramsar.org/pdf/res/key_res_x_26_e.pdf>, at paragraph 1 .
} 
as the enabling tool to envisage the damaging impacts. ${ }^{69}$ Where adverse effects are established, appropriate regulation and management of harmful processes are recommended. ${ }^{70}$ Land area for conservation needs to be increased (and degraded ecosystems need to be rehabilitated) through appropriate management. ${ }^{71}$ Obligations go slightly further in the case of the Ramsar Convention, where compensation is expected in the event of adverse impacts. ${ }^{72}$ However, while the Ramsar Convention indeed foresees compensation, it does so only in those cases where destruction of existing wetlands on the grounds of 'urgent national interest' leads to a deletion or restriction of a listed wetland. ${ }^{73}$ The situations in which compensation is anticipated is fairly small and these are better seen as an exception rather than the rule.

The requirements in biodiversity treaties are generally less clear, less specific and less strict than the principle of mitigation hierarchy developed by the BBOP. The mitigation hierarchy principle makes some attempt at specifying the meaning of appropriate 'management' and lists its individual stages. Notably, the principle of mitigation hierarchy is not qualified by the international law wording of "shall, as far as possible and as appropriate'. ${ }^{74}$ This principle appears to elaborate on provisions from the relevant conservation treaties.

However, critics warn that despite these principles, the BBOP would not prevent biodiversity offsets from allowing and legitimizing the avoidable destruction of habitats, undermining planning laws that prevent destruction, and opening up new opportunities for further exploitation of biodiversity. ${ }^{75}$ These critiques directly challenge the BBOP's claim that biodiversity offsets can lead to 'more and better conservation'. ${ }^{76}$ The principle of mitigation hierarchy, critics argue, will be difficult to enforce, given that the option to offset is at the discretion of project developers. This seems a particularly likely scenario in cases where the authority that issues standards or sells offsetting projects also assesses projects' performance - in such cases, the authority clearly has an interest in confirming compliance.

In evaluating the contribution of offsets, it is reasonable to ask whether the overarching goal of no net loss can be achieved at all. ${ }^{77}$ The nature of biodiversity problems speaks against this being possible, even when established methodologies are followed closely. The predominant reason is that ecosystems often have functions, which are specific to space and time, thus making an exchange of one ecosystem for the other an ecologically sensible transaction only in very rare cases. ${ }^{78}$ The challenge of ensuring that 'like' is

${ }^{69}$ CBD, n. 8 above, Article 14; Ramsar Convention, n. 9 above, Article 3.

${ }^{70} \mathrm{CBD}, \mathrm{n} .8$ above, Article $8(\mathrm{f})(\mathrm{l})$.

${ }^{71}$ Ibid.

${ }^{72}$ Ramsar Convention, n. 9 above, Article 4.2.

${ }^{73}$ Ibid.

${ }^{74} \mathrm{CBD}, \mathrm{n} .8$ above, Article 8.

${ }^{75}$ G. Monbiot, 'Biodiversity Offsetting Will Unleash a New Spirit of Destruction on the Land', The Guardian (7 December 2012); n. 3 above.

$76<$ http://bbop.forest-trends.org/>

${ }^{77}$ The BBOP defines 'no net loss' as both a principle for biodiversity offsets and its goal. See, e.g., BBOP, 2013, n. 28 above, at 6 (defined as one out of ten principles) and at 14 (defined as a goal).

${ }^{78}$ J. Salzman and J.B. Ruhl, 'Currencies and the Commodification of Environmental Law', 53:3 Stanford Law Review (2000), 607, at 616-630; C.T. Reid, 'Between Priceless and Worthless: Challenges in Using Market Mechanisms for Conserving Biodiversity', 2:2 Transnational Environmental Law (2013), 217, at 221-225. 
traded for 'like' lies in the difficulty of defining a valid trading unit. ${ }^{79}$ Finally, despite the attempts at estimating the total economic value of ecosystem services, ${ }^{80}$ such exercises remain contested and the comprehensive role of ecosystems is difficult to arrive at. ${ }^{81}$ Thus, an offsetting outcome may achieve the same number of hectares of a habitat that has been destroyed, but it does not guarantee that habitats are functionally equivalent to those lost, or that the functions preserved are of the same quality. In some cases, such as large infrastructure projects, the effects of development on biodiversity may be so grave as to be impossible to offset: while these cases can be justified under the argument of a clear and overriding public interest, no net loss cannot be claimed. ${ }^{82}$ Ensuring permanence, additionality and no leakage of offsets are other significant issues that touch upon environmental integrity, ${ }^{83}$ as are monitoring, reporting and verification (i.e., enforcement) activities, which ensure that the intended objectives of a project have been met. These technical details should not act as a distraction for an often forgotten fact: that offsetting projects cannot create new habitats, but merely turn an existing habitat into another one. ${ }^{84}$

As it emerges, despite the legitimacy that the CBD's and the Ramsar Convention's recognition appears to bestow on the BBOP's operation, the principles that the BBOP promotes are not without issue and reflect a particular, rather than universal, interpretation of the action required under treaty provisions. The existence of the principles of 'no net loss' and 'mitigation hierarchy' provide a way for claiming compliance with international biodiversity objectives, when more stringent alternatives could be pursued, such as stronger limitations on the activities that cause biodiversity loss in the first place. The effect of such principles may be to inhibit the progress towards more radical trajectories that could be read into international legal provisions alongside the practical ones. The vigorous backing that biodiversity offsets have received by corporate actors provides some evidence that biodiversity offsets stem from this pragmatic but also weaker interpretation of international law. The principle of no net loss now represents a unifying platform not only for pledges of corporate leaders but also for their appeals to governments to adopt the policy framework for no net

\footnotetext{
79 Ibid.

${ }^{80}$ See, e.g., R. Costanza et al., 'The Value of the World's Ecosystem Services and Natural Capital', 387:6630 Nature (1997), 253; The Economics of Ecosystems and Biodiversity (TEEB), Mainstreaming the Economics of Nature: A Synthesis of the Approach, Conclusions and Recommendations of TEEB (2010).

${ }^{81}$ See, e.g., M.M. Robertson, n. 14 above.

${ }^{82}$ T.E. Gardner et al., 'Biodiversity Offsets and the Challenge of Achieving No Net Loss', 27:6 Conservation Biology (2013), 1254, at 1264.

${ }^{83}$ Permanence, additionality and leakage are part of the jargon of contemporary conservation management. 'Permanence' means that results of a certain conservation activity should persist over a sufficiently long period of time; 'additionality' refers to ensuring that conservation efforts are additional to outcomes that would have resulted in the absence of a scheme; 'leakage' occurs when effects of harmful activities are geographically displaced to another part of the world. The importance of these safeguards was debated foremost in the context of the Kyoto Protocol's Clean Development Mechanism. For a summary of these issues, see the recent European Commission consultation on the 'no net loss' approach, found at: <http://ec.europa.eu/environment/consultations/nnl_en.htm>.

84 G. Monbiot, 'The Unsung World' (12 August 2012), found at:
<http://www.monbiot.com/2012/12/08/the-unsung-world/>.
} 
loss. ${ }^{85}$ It is found also in internal corporate policy statements. ${ }^{86}$ But the no net loss principle is not limited to the business approach. As indicated in the introduction, it may well be developed into an EU-wide policy and it is likely that from there it will inspire other national policies. These are some of the signs signalling that no net loss has been favoured over a stricter preventative approach.

\section{CONCLUSION}

The examination in this article of biodiversity offsets from a transnational perspective can be concluded on a note that is familiar to several stories in other environmental regimes. With intergovernmental action lagging behind the scientific warnings, developments outside the multilateral processes can be commended and it is tempting to avoid critique. ${ }^{87}$ Nevertheless, scholars must critically yet constructively engage with the transnational governance arrangements to assess how they function and to examine their role in the wider governance architecture. This article has portrayed the BBOP and biodiversity offsets not only as part of the governance architecture for biodiversity, but specifically as falling also within international treaty law. The emphasis in the article has been on the interplay of norms in the spheres of transnational law and international law, and particularly on demonstrating how a policy implementing a specific interpretation of treaty provisions and treaty's strategic documents may in turn be imported back into the treaty process and consolidated as the standard and accepted reading of the norms.

With such policy impacting back onto the treaties, especially the reading of the norms they contain, my interest has been also in highlighting some of the other possible interpretations of the same norms and presenting them as expectations of international legal provisions that remain unfulfilled. Examination of how diverging interpretations develop from the same treaty provisions and strategic documents, and by whom, highlights how coalitions of the large and powerful may also lead to the exclusion of certain voices in the design of regulatory tools, such as the BBOP. This has served two purposes. One is that the study of opposing groups challenges the claims that schemes are internationally agreed. My argument here is that a better understanding of the functioning of transnational governance requires an examination of the voices that remain weak, or of the visions that are not realized through law. The contestations that occur behind the cooperative surface between a variety of actors are no less characteristic of transnational law than its conjoining power. The second, perhaps resulting, purpose of the study of the marginalized voices is to remind us of the improbability of actually reaching a consensus, given the fundamental differences in the world views and preferred strategies.

This examination of biodiversity offsets in transnational governance has pointed to some of the issues that this mechanism raises for lawyers, but falls short of a systematic

\footnotetext{
${ }^{85}$ University of Cambridge Programme for Sustainable Leadership, 'Natural Capital Leadership Compact', found at: <http://www.cpsl.cam.ac.uk/Business-Platforms/Natural-Capital-LeadersPlatform/Natural-Capital-Leadership-Compact.aspx $>$.

${ }^{86}$ Thirty-eight companies have public company-wide, biodiversity commitments relevant to no net loss; this number has been steadily increasing since 2002. See The Biodiversity Consultancy, 'Private Sector No Net Loss Commitments' (2012); found at: <http://www.thebiodiversityconsultancy.com/wpcontent/uploads/2013/07/Private-Sector-No-Net-Loss-commitments2.pdf >.

${ }^{87}$ See V. Heyvaert, n. 5 above, at 89.
} 
study of the phenomenon. Further scholarly engagement will need to match the enthusiasm for the development of similar initiatives by policy makers.

Jerneja Penca is a postdoctoral fellow at PluriCourts, Centre for the study of the legitimate roles of the judiciary in the global order at University of Oslo. She holds a $\mathrm{PhD}$ in law from the European University Institute (EUI) and an LLM (with distinction) from the University of Nottingham. The author would like to thank Jo Hawkins and two anonymous reviewers who read and commented upon earlier drafts of this article. The author alone remains responsible for any errors or omissions it may contain. 